\title{
An Overview on the Dimensions and Pillars of Justice in Islam
}

\author{
Mohammad Reza Akhzarian Kashani ${ }^{1}$ \\ ${ }^{1}$ Center for Higher Studies of the Islamic Revolution, University of Tehran, Tehran, Iran \\ Correspondence: Mohammad Reza Akhzarian Kashani, Center for Higher Studies of the Islamic Revolution, \\ University of Tehran, Tehran, Iran. E-mail: makashani@ut.ac.ir
}

Received: May 16, 2017

Accepted: May 18, 2017

Online Published: June 5, 2017

doi:10.5539/res.v9n3p1

URL: http://doi.org/10.5539/res.v9n3p1

\begin{abstract}
Justice is one of the questions and the ideal principles of Islamic thought, which has a special place in Islamic thought. The importance of justice in Islam is to such an extent that the justice are known of conditions and characteristics of the nature of divine that without it the God would not be complete and accordingly Muslim thinkers have explored different aspects of it. This trend and attention to the concept of justice in Shi'ite thought have found high place so that Shiite justice is considered as its own religion principle and rejection and the doubts it knows the out of Islam and as blasphemy and apostasy. The concept of justice has not still been fully understood and there is no consensus among everyone in introduction and understanding it. In this paper, we want to review on this basic concept by evaluating the dimensions and justice features in the Shiite thought.
\end{abstract}

Keywords: justice, Islam, Shiism, thought

\section{Introduction}

Justice is one of the things that a man has in his own nature and human nature and has been inspired as piety and license to him. Justice is a very broad concept which, while seeming simplicity, has been combined with the many complexity so that Plato starts his Republic book by question of "What is justice?" And yet today, after more than two thousand years the concept of justice still remains unclear and thinkers and philosophers and economists and lawyers is still trying to find the correct meaning of it. Justice is raised among the key concepts of policy as an abstract concept although cannot be provided external sense of that easily but is understandable and desirable for most human societies. On the other hand, unlike many of common concepts in political and philosophical field that has no much validity the concept of justice have much reliability and has been among sustainable concepts of political thought that has used the minds of many thinkers.

\section{The Importance of Justice in Islam and Shi' ism}

Great philosophers have identified four basic principles for justice and have called them as human rights. On this basis any law, which meet the following four principles and to show more respect to them, has been along with the greater share of justice. The natural human right is the right to life which no one is permissible to deny his natural right. This right is the source of other rights, including defense. The second natural human right is the right to live in creature with reason and human society is required to makes free a man in this natural talent. A third natural right of man is freedom choice of work and land use, etc. and on its requirement any person can use of land and what has been created on that with his own choice and no one stop him from activities and his effects unless his capture and activity to be required to violation of others' rights. The fourth natural right of man is equal right of every individual with other people in rights so that the ruler and the people, rich and poor are equal in the law and the authorities of their legitimate rights.

Any law, which includes such features and to be observance of this principles of natural law has a higher percentage of Justice in himself and of that would be fairer and legislation that does not contain of that would be incomplete or ruthless. Islam as the last divine religion first has shown special attention to the right to life and Islamic law has tried in the respect and protection of the right over the any law. The Holy Quran manslaughter without legal authority has considered of the greatest sins:

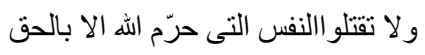

And punishment for such a crime has known the hell everlasting torment:

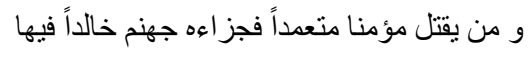


And the Prophet (pbuh) has said about the importance of preserving the lives of believer Muslim:

$$
\text { لزو ال الدنيا أيس على الله من قتل المؤمن }
$$

Second, Islamic law, is the first Sharia that has known a man as intelligent beings and thoughtful, therefore the Quran, has talked with a man and has argued with him as familiar characters to his profits and losses to the extent that even a rational argument is wanted of the infidels:

$$
\text { أاله مع الله قل هاتو ا بر هانكم ان كنتم صادقين }
$$

Islam puts the value of reason and thinking as the best principles and goals of his calling and by addressing the human thinking has spoken with him as a sentient beings and the understanding owner. Several signs indicate that human thought are the witness of this saying.

Thirdly, Islam has strongly encouraged people to exploit the land and its owned and effort in agriculture and commerce and the manufacturing industries and by on the effect of these encouragements Muslims in early Islam with Curious robbery shortly all the beneficial legacies of Greek and Roman civilizations of India and Iran attached to their emerging civilization. In this sense also has been emphasized in various verses:

$$
\text { و لقد مكنّا كم فى الارض و جعلناكم فيها معايش }
$$

We put your hands in the earth free to a variety of occupations and livelihoods supplies and equipment to provide your life in of that. Or in another place says:

$$
\text { هو الذى جعل لكم الارض ذلو لاً فامشو ا فى مناكبها و كلو ا من رزقه }
$$

Of that in addition to notification that in his blessings says: he who has subdued Bronco unburden the earth under your will curb. To move around the earth and the God of eat that this highlights is the importance of Islam to business and business freely that God has provided its field.

Fourth, Islam makes no distinction between the ruler and the people, rich and poor not care about and knows classes of people both for creation and for equal rights:

$$
\text { يا ايها الناس انا خلقناكم من ذكر و انثى و جعلناكم شعوباً وقبائل لتعارفو ا انّ اكرمكم عنداله اتقيكم }
$$

These four characteristics has been caused the Islam the religion of Islam as a religion coherent and coordinate completely to underpin the fairest rules for human life and to interduce Islam as a religion and justice to the world.

Islam has emphasized the extent to justice that in many traditions quoted from the infallible Imams (as) has been emphasized on it a lot and even has known it as an integral aspect of Islam. Such traditions are as follows:

Of The Prophet (PBUH) has been quoted:

$$
\text { عدل ساقه خير من عباده سبعين سنه قيام ليلهاو صبام نهار ها }
$$

One hour of justice is better than seventy years of worship that its days have fast and at nights have of resuscitation. Or elsewhere he said:

$$
\text { لعمل الامام العادل فى رعيته يوماً واحداً افضل من عباده العابد فى اهله مأه عام او خمسين }
$$

Dayly act of the leader that to behave justice among people is the hundred or fifty year's action of who is praying among their families is better. Imam Sadiq (AS) said:

$$
\text { الامام العادل لاترّد له دعوه }
$$

Never is rejected the prayers of a righteous leader. And Ali (AS) said:

$$
\text { فى العدل صلاح البريه والاقتداء بسنه الله و العدل حياهو الجور ممات }
$$

Justice is both public interest and following the divine way and justice of the life and injustice is death. Accordingly, the Imams (AS) justice have known as integral components of Islam and have allocated high position value for that. This mainstream of thinking makes equality in Muslim people and Islam knows equal all on his rules and regulations.

The purpose of the prophets is that faith in God is so alive in people and so to create morality and mindset of God in the fabric of the community stand up to justice and to constitute the just society:

$$
\text { لقد ارسلنا رسلنا بالبينات و انزلنا معهم الكتاب و الميزان ليقوم الناس بالقسط }
$$

And the existence of a just society requires both spiritual and material strength and the clear arguments, Hadid is essential for the establishment of justice establishment. 
By referring to the history of science in Islam also see that justice issues have been at the top of theological issues. And the question of predestination and necessity and freedom that has tied directly with discuss of divine justice and has been the focus of philosophers and scholars of speech. Muslim community which has many causes to quickly entered the stage of scientific thinking was based the problem of necessity and freedom as its first topic discussed and was led to appearance of two Ash'arites and Mu'tazila thinking, but this view has been attached on the one hand to delegate and on the other to force with all the controversy that has been provided was failed to respond to the many doubts and questions of the Muslim so the basis was provided for expand and more attention to Muslims and Shiite thought in this regard. From the perspective of Shiite neither algebra nor delegated, but the affair between things has been accepted. From the perspective of Shia will of man is not enough to delegate to him, and God is not cause to coercion and violating absolute impossibility, but God has the ability and the authority and the will for mankind to try to gift obedience or disobedience, and is deserving of reward or punishment. On the other hand his will is limited to God's will to the extent that the Divine will also to accompany it. Human in his interested works is optional, not independent, and not as a mere instrument, but is done as far as his divine power and authority of God's will. Benevolent eye on grace of God and evil arises from hindrance and submission to God and God Hindrance in the effect of belief benefit or his behavior or ungrateful of its grace.

\section{Justice in Shiite Jurisprudence}

Justice in the word is used means to mounting or means to endurance or both means. However, the purpose of God and religion scholars and jurists of justice has been expressed in different ways. Some of justice have considered as mental state that is of attributes of spirit and have mentioned it as sensual quality terms, carnal, sensual Board, Abiding Board, and Sensual Queen. The common point in all these interpretations is that justice reinforces and strength the virtue. Seyyed Mohammad Kazem Yazdi (ra) in Orvato alvosgha book says: Justice is the doing queen to obligation and forbidden to taboos. Sheikh Morteza Ansari (RA) in the treatise the same meaning knows famous after Hilli among literal scientists. So by definition, justice is a mood state in human in which he takes to the piety and abstinence from all sins and makes human to respect the compassion and manhood. In other words justice have to lake of doing sin, or in addition to that, lake of necessities and others have defined the justice to the great sins doing and insisting doing little sins that Sabzevari scholar and Allameh Majlisi have chosen the same meaning.

A third definition of justice has been stated that justice is the practical strength based on mental mood and permanent Queen in-esteem, which in this definition two features are listed to justice: first, the action and the act means performing all duties and leave all taboos and insisting on the small sins and other psychological mood that is the same queen and the board and the sensual states. This definition can be found in the words of Ibn Babooyeh, Sheikh Mufid and others. Other definitions of justice that not-so-famous, such as: just is someone who is Muslim and not seen a sin of him and someone who has a good appearance. Ibn Junaid and Shaykh have mentioned the sense of justice. But in general we can introduce several conditions for justice that has been filed in various narratives:

1) To be among veil and chastity people and maintain him of eating forbidden and adultery.

2) To leave the great sin that God has promised hell to commit them. Such as drinking alcohol, adultery, usury, rights of parents, fleeing war and...

3) All their imperfections and sins of the people do not cover a person from his sin.

4) In the congregational prayers be active participation.

5) Does not lie to people, does not promise and does not oppress anyone.

6) To be reliable and trustworthy of people.

7) When to evaluate in local search on it the people tell we did not see except good things.

8) Guilty as charged, to be not suspected traitors and people.

9) To be not chess players, gambling, singer, listener.

In general it can be said that just Muslim is who to be not seen sin of him or if it was seen is committed to the precepts of Islam. The testimony of such a man is accepted, and his righteousness is fixed. Such a person must have both the Justice Queen and are guilty of anything in private. 


\section{Meanings and Types of Justice}

Three meanings on the concept of justice can be noted that various scholars have discussed accordingly:

A) Justice means to intention: if we consider a set that different components have used on it and the special purpose is targeted to it, should be respected certain conditions in terms of the necessary amount of each component and the quality of the relationship between the components and only in this way that this set to can be remained and to give your desired effect. This equilibrium can be cited the social, economic, political, cultural, physical, and chemical aspects. Justice in Islam has used in the sense used for intention and moderation in the creation system. The opposite of this is disproportionate not means of oppression. Therefore some of that sense of proportion and disproportion to doubt God responded oppression have not been very successful. Justice means harmony of dignity wisdom and knowledge of God. Common wisdom and knowledge of God and his requirements for building anything knows how much anything is necessary.

B) The second meaning of justice, equality and rejecting any discrimination. What is in moral justice are used to be called, for example, that someone is justified by the same means. That person is no difference between people not discriminate and therefore the sense of justice, of equality. Of course, the sense of justice does not mean that everyone and everything with an eye seen. It is the same oppression. It means that with equal entitlements to be treated equally which means induces the expression of a third sense of justice that comes after this.

C) Justice means to grant the parties of his right. In this sense, respect, merit and granted to each beneficiary has been entitled to what with merit it is considered the true meaning of justice. This just depends on two things: one is right and priorities means the human beings to each other and compared to each other find somehow the rights and priorities. Another is characteristic of human nature that has been created so that in their work and necessarily to be used a credit ideas and by helping them achieve their natural goals. This ideas are essay and are specified should be or should not be. This sense of justice and is against oppression and to answer the question of God must understand the concept of justice.

\section{Administrative Bases for Justice}

Islam attaches several basic foundations for social justice that forms the basis of justice in Islam. One of these foundations is freedom of conscience if social justice need to recognize the intrinsic merit of the individual and society and along with the belief that justice will not lead to a great cause of humanity will never happen. This belief that life without God's hand will not come to fruition.

As well as another requirement of that is liberation and freedom of the soul and conscience and the apparent values of the community. Islam has seen in all appearances of society with a view to adoption but it has set for each special place and has condemned excess and wastage for each one.

The realization of social justice is the basis of full equality of humanity. One of the major fields for the implementation of social justice is that human beings are equal in various fields. But this equality does not mean that all are equal in all conditions but also means that the intrinsic merits and abilities and... To be seen equal with them and those who have the same entitlement to be considered equal.

Social strong cooperation is the third base for the implementation of the social justice. No doubt without cooperate in all fields of people in a society realization of social justice is impossible or nearly impossible. If there is no sense of justice in field for the tendency of people to run it also will not exist.

On the other hand justice is the equipment required that the possibility of realization of justice on that society is impossible. These means are inner and conscientious means that depends on breath and people inner. One of these means is self-purification through which compels man to justice rights of others. On the other hand has put the fear of God that divine punishment is one of the means and also has put rewards for the man that to give them in consideration of justice. Another aspect of external means and equipment can be noted that financial law, such as poor-rate, alms and charity can be noted.

As has been emphasized in Islam to justice and its implementation and many verses has dedicated to it. Among them:

$$
\text { ان الله يأمركم أن تؤدوا الامانات الى اهلهاو اذا حكتم بين الناس ان تحكمو بالعدل ان الله نعما يعظكم به انّ الله كان سميعاً بصيرا }
$$

Of that is apparent that judgment among people judge among human beings should be along with justice and justice behave is good things for God. Or he says:

$$
\begin{aligned}
& \text { يا ايهاالذين امنو ا كونوا قو امين بالقسط شهاء لله ولو على انفسكم او الو الدين و الاقربين ان يكن غنياً او فقبراً فالله اولى بهما و لاتتبعوا الهوى ان }
\end{aligned}
$$

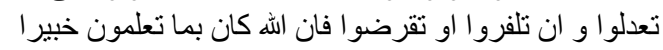


Who orders to believers that to behave in justice and to avoid of the order that the justice act and the desire to avoid of velleity the follow of lust removes the human of justice that in this verse lake of implementation of justice has been mentioned in synonym of volleity. Or in another verse says:

يا ايها الذين امنوا كونوا قو امين لله شهداء بالقسطو لايجر منكم شنان قوم على الا تعدلو ا اعدلوا هو اقرب للتقوى و اتقو الله ان اله خبير بما تعطلون

Which one of the features of witnesses has noted as justice and knows them one of the factors of piety and closeness to God.

\section{Dimensions of Justice}

Islam has shed the justice in all aspects of human life and not only in judgments but also in most detailed social and individual aspects has considered necessary. Consideration of justice in prase and criticism is among these fields and it has been recommended to done moderation in praise or criticism of others. Ali (AS) said in this regard says:

$$
\text { الثناء باكثر من الاستحقاق ملق و التقصير من الاستحقاق عيّ اوحد. }
$$

If you prise excessive than others' merit you are flattery person if you did not pluck to prase enough you are jealous. Elsewhere he said:

$$
\text { الافر اط فى المسلامه يشبّ نير ان اللحاجه. }
$$

Indulgence in blame could be kindled the fire of obstinacy.

As praise of the righteous servants the observing in moderation in charity has been introduced as one of their characters.

$$
\text { و الذين اذا انفقو الم بسرفو او لم يقتروا و كان بين ذلك قواماً. }
$$

Which it represents the justice in charity and spending? As recommended in Islam to establish justice at home and even Islam allows to have many wives but it has provided justice and this in the event of failure to ability to implementation of justice among the wives has not correct.

If you fear that you cannot establish justice among wives to satisfy on a wife.

Other field of consideration of justice that includes an important part of human social life is economic justice.

Islamic economic system has been based on justice and is in such a way that the right of any person is not wasted. Thus, even for daily hours of a man's life has been set the just plan. And has divided to a few hours to work and worship and entertainment and has interduced its reason as providing material and spiritual needs of the human being. Or for the distribution of facilities of the society has ordered to justice and equality. As Ali orders to the Malek Ashtar to be divided for farthest corners of the country equal to it is divided for nearest parts.

As well as the condition of justice has put for consumption, and has known waste the extra consumption has introduced it as the worst features of the unbelievers.

Islamic has required the justice in some extent that has required it for workship and has also required consideration of moderation in workship

So much so that Imam Sadiq (AS) says:

. الاتكر هو ا الى انفسكم العباده.

Do not impose on their worship. Especially has been recommended to care more of education of children the justice in their workship.

These descriptions and features has been led to recognize the Islam as most perfect divine religion as a justice religion and justice to be known of basic conditions of Islamic state and society. In Islam, the justice has been not only recommended about friend and with other Muslims but also it has been recommended to observing it in waring.

$$
\text { فان قاتلو كم فاقتلو هم كذلك جزاء الكافرين. }
$$

If enemy kills you, you kill them too. Yes, the recompense of the unbelievers is in such. The justice here is killing and otherwise is fear and cowardice.

$$
\text { و و من قتل مظلوماً فقد جعلنا لوليه سلطاناً فلا يسرف فى القتل }
$$

Anyone who to be killed innocent we have but he mastered and powers for them but the victim's parents have no right to waste their revenge. 


$$
\begin{aligned}
& \text { فمن اعتدى عليكم فاعتدوا عليه بمثل ما اعتدى عليكم و اتقو الله. }
\end{aligned}
$$

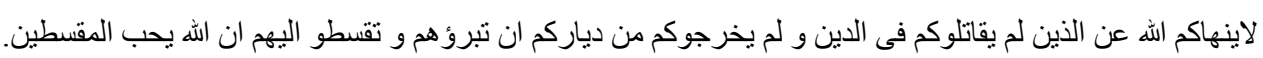

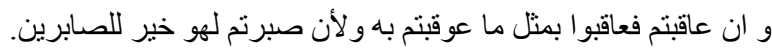

$$
\begin{aligned}
& \text { و لايجر منكم شتآن قوم على الا تعدلو ا. }
\end{aligned}
$$

Accordingly, for the implementation of justice in Islam has put various means and equipment. In addition to education and Islamic teaching has accompanied the right sword with it and retaliation, as well as has interduced guarantor of social justice.

\section{Deviation Factors from the Justice}

As it was said the justice rooted in human nature and every human based on nature of human are required the justice but for various reasons natural features may sometimes be forgotten. The Holy Quran has expressed several factors of deviation of the justice:

The first factor is self-love and interests and relationships:

$$
\text { يا ايها الذين امنو ا كونو ا قو امين بالقسط شهذاء لله ولو على انفسكم او الو اليدن و الاقربين ان يكن غنياً او فقيراً فاله اولى بهما }
$$

O you who have believed, to upris quite to the justice and your certificates to be only for God, even if to be against yourselves or your parents and relatives and be poor or rich has no effect on your witness because the God is more worthy to support them. This verse points out to the dangerous interest that leads to withdrawal of justice.

The second factor of deviation from the justice is discomfort and dissatisfaction of certain individuals or groups that did not adhere to their rights:

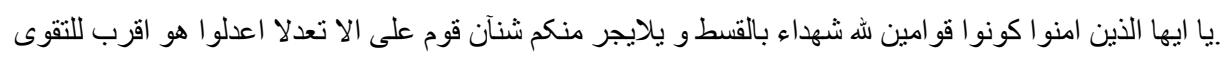

O you who believe, your program to be sincerely uprising and fair testimony. Ethnic animosities to be not led your perversion of border of the justice and to behave in justice that is closer to the piety. The third factor can be considered as bribes and eating unlawful and void.

$$
\begin{aligned}
& \text { و لا تأكلوا امو الكم بينكم بالباطل } \\
& \text { و تدلوا ايها الى الحكام لتأكلوا فريقاً من امو ال الناس بالاثم و انتم تعلمون. }
\end{aligned}
$$

Do not eat each other's property to false and wrong in their midst. And to eat part of the public property to sin, do not give part of it to the judgment while you know acquiring it is forbidden. Quran interduces such factors as outing fields of the boundaries of justice and believes that to establishment of justice should be universal and permanent supervision over the affairs of society and the rule of enjoining good and forbidding wrong is one of the most important ways to achieving this goal.

\section{Summary and Conclusion}

Addressing the Islamic thought and in particular the issue of governance in Islam without justice is not only achieves the good final but also has provided erroneous interpretation of the principles of Islam and is delivered the distracted strategies and solutions. To understand the basis of individual, social and political of Islam it is necessary that both the definitions to be proposed and dimensions and elements of each dimension to be considered because the definition contains and carries different aspects of justice in Islam, that in place it is appropriate and necessary, but has different function. Political definition of justice certainly leads to political explanation of that the different aspects with economic definition of it is available and the same is true in the face of individual aspects of justice. For this purpose it is necessary to obtain a true and comprehensive understanding of the justice and its foundations in a combined process and then appropriate measures be selected according to each approach.

\section{References}

Belaghi, S. D. (1981). Justice and the judiciary in the Islamic. Kabir.

Dastgheib, S. A. H. (1984). Justice. Education Center, Shiraz.

Gherati, M. (n.d.). Social justice, the institution in the right way. Qom, Bi Cha, Bita.

Gherasti, M. (n.d.). Justice and social justice. Islamic Publications Office.

Haghi, M. (1994). Justice and bribery of Islam. Islamic Publications Office.

Mohammadi, R. S. M. (1989). Justice and unity in the world. The center of Islamic Publications Bureau. 
Motahhari, M. (1976). Divine Justice. Islamic Publications.

Seyyed, Q. (1983). Social justice in Islam.

Rahbar, M. T. (1985). Political lessons of Nahj al-Kabir.

\section{Copyrights}

Copyright for this article is retained by the author(s), with first publication rights granted to the journal.

This is an open-access article distributed under the terms and conditions of the Creative Commons Attribution license (http://creativecommons.org/licenses/by/4.0/). 